\title{
From Moscow with a Mushroom Cloud? Russian Public Attitudes to the Use of Nuclear Weapons in a Conflict with NATO
}

\author{
Michal Smetana \\ Charles University \\ Peace Research Center Prague \\ Experimental Lab for International Security \\ Studies (ELISS) \\ Prague, Czech Republic \\ michal.smetana@fsv.cuni.cz
}

\author{
Michal Onderco \\ Erasmus University Rotterdam \\ Dept. of Public Administration and Sociology \\ Experimental Lab for International Security \\ Studies (ELISS) \\ Rotterdam, The Netherlands \\ onderco@essb.eur.nl
}

\section{Keywords}

Russia; NATO; nuclear weapons; survey experiment; public opinion; moral foundations theory

\begin{abstract}
This article presents findings of an original survey experiment on public attitudes toward nuclear use conducted on a representative sample of Russian citizens. We randomly assigned our participants to experimental treatments with vignettes describing a military conflict between Russia and NATO in the Baltics, where Moscow considered a limited nuclear "escalate-todeescalate" strike to avert defeat. Our findings show that Russians are significantly more averse to nuclear strikes than to the corresponding use of conventional missiles. The participants disapproved similarly of a demonstrative nuclear explosion in an unpopulated area and of nuclear strikes in a more escalated scenario. We also found associations between the moral values of individuals and strike support corresponding to earlier studies in the United States. Finally, our participants reported similar concerns about both nuclear and conventional strikes, with the worry about civilian casualties and the suffering of victims at the top of the list across experimental treatments.
\end{abstract}

This is a pre-print that is currently under peer-review in an academic journal. 


\section{From Moscow with a Mushroom Cloud?}

Russian Public Attitudes to the Use of Nuclear Weapons in a Conflict with NATO

\section{Introduction}

Almost a decade ago, Press, Sagan, and Valentino (2013) made a splash in our field with an original survey experiment on public attitudes to nuclear weapon strikes. Their findings demonstrated that American citizens were significantly less averse to the military use of nuclear weapons than previously thought, setting off a new wave of research into the nuclear nonuse norm, or the "nuclear taboo." Unlike earlier historical accounts of high-level decision-making (Tannenwald 2007; Paul 2009; Sauer 2015), this new wave has continued using large-N surveys to examine public attitudes toward the use of nuclear weapons under different experimental conditions (e.g., Sagan and Valentino 2017; Haworth, Sagan, and Valentino 2019; Rathbun and Stein 2020; Koch and Wells 2020; Montgomery and Carpenter 2020; Smetana and Vranka 2021; see Smetana and Wunderlich 2021 for a review). There is, however, an apparent gap in this body of scholarship: with rare exceptions (Sukin 2020; Egel and Hines 2021), there are few studies that examine public views on nuclear use outside of the United States, and even fewer examine these attitudes in non-Western countries. ${ }^{1}$

Arguably, the key non-Western country for which we currently lack this kind of experimental evidence is the Russian Federation. Russia possesses the largest nuclear arsenal among non-Western countries, and it is the only nuclear-armed state that can compete with the United States in the number of nuclear warheads and their delivery systems (Kristensen and

\footnotetext{
${ }^{1}$ We are also aware of two unpublished survey experiments examining the views of Israeli (Horschig 2021), and Israeli, French, and British (Dill, Sagan, and Valentino 2021) citizens.
} 
Korda 2021). Since the early 2000s, Moscow appears to have increased its reliance on nuclear weapons in its security doctrine and repeatedly used thinly veiled nuclear threats. The Russian 2014 annexation of Crimea has led to the dramatic deterioration of East-West relations and the return of great power competition as the main strategic concern in the "third nuclear age" (Smetana 2018; Cooper 2021; Futter and Zala 2021). The 2021-2022 standoff at the Russian border with Ukraine that threatens to escalate into a full-scale war in Eastern Europe further highlights the significance of the Russian case and underlines the need to gain new insight into Russian views on the use of nuclear weapons.

To address the lack of such studies in the Russian context, we conducted a survey experiment on public attitudes toward nuclear use on a representative sample of 1,507 Russian citizens. Rather than merely replicating earlier experimental work in a different national setting, our aim was to design an original survey revolving around fictional but realistic scenarios that reflect the urgent geopolitical concerns in the contemporary international security environment.

To this end, our participants received vignettes describing a military conflict between Russia and NATO countries in the Baltics. Many Western analysts argue that this is where the threat of Russian nuclear use primarily lies nowadays: facing conventionally superior NATO armies, Moscow could conduct a limited nuclear strike to "de-escalate" the conflict, compel NATO to meet the Russian leadership at the negotiating table, and ultimately score a political victory (Davis et al. 2019; Kroenig 2018; Kühn 2018; Sokov 2014; Zysk 2018; Cimbala and McDermott 2016; Luik and Jermalavicius 2017; Fink and Oliker 2020; Schneider 2018). ${ }^{2}$ Given that nuclear weapons have not been used in warfare since 1945 and their employment would

\footnotetext{
${ }^{2}$ Importantly, there are also significant voices arguing that the idea of Russian "escalate-to-deescalate" strikes is a dangerous Western myth that does not correspond to the Russian nuclear strategy (Ven Bruusgaard 2017; 2020; Oliker and Baklitskiy 2018). The idea, nevertheless, remains influential in Western strategic thinking and greatly influenced the 2018 U.S. Nuclear Posture Review (Smetana 2018).
} 
certainly be seen as an extraordinary measure by the Russian public, our scenarios portray a high-stakes situation where nuclear use could conceivably prevent a strongly undesirable outcome for Moscow - that is, a defeat in a prominent, great power conflict.

In the experiment itself, our first aim was to examine the baseline difference in Russian public support for nuclear and conventional strikes and to explore the elasticity of Russian views on nuclear use with respect to the expected collateral damage and the shifts in conflict intensity. To do so, we randomly assigned our participants to experimental treatments and investigated the differences in their support for (1) a nuclear strike against a NATO military base and the corresponding use of conventional missiles; (2) a nuclear strike against the military base and a purely demonstrative nuclear explosion; (3) and a nuclear strike when the conflict remains limited outside of the borders of Russia and when it escalates to attacks on the Russian territory proper.

Our second aim in the experiment was to engage with the recent literature on public attitudes toward nuclear use in the United States that draws on the Moral Foundations Theory (MFT) from moral psychology (Rathbun and Stein 2020; Smetana and Vranka 2021). In particular, we intended to examine whether the association between moral foundations of individuals and the public aversion to the use of nuclear weapons also holds in a non-Western country or whether this is a culturally-specific dynamic in the West. Moreover, building on Smetana and Vranka (2021), we investigated whether the MFT approach allows us to identify any specific moral barriers with respect to nuclear strikes or whether the relationship between moral foundations and strike support is essentially the same for both nuclear and conventional weapons.

Finally, our third aim was to explore the reasoning behind our participants' approval or disapproval of the use of nuclear weapons in our scenarios. We asked them to evaluate the relative importance of twelve potential concerns, which reflect the various theoretical 
explanations of nuclear nonuse in world politics. We also examined to what extent these concerns are specific to nuclear weapons as opposed to conventional strikes and how the relative importance of these concerns differs between those participants who approved of a nuclear strike in our scenarios and those who disapproved of it.

Our findings show a clear pattern of a strong aversion to nuclear weapon use among Russian citizens, with an overwhelming majority preferring to face the prospect of military defeat than to agree with a nuclear "de-escalatory" strike against a NATO base in Poland. The disapproval of nuclear strikes remained stable even in the treatments where these weapons were stripped of some of their main negative side effects (as in a demonstrative explosion over an unpopulated area) or when a war in the Baltics spilled over into Russian territory. With respect to the MFT, we found that, as in the United States, the "individualizing foundations" were associated with higher aversion toward nuclear use and the "binding foundations" with lower aversion - but we also demonstrate that these associations were not nuclear weapons-specific and applied correspondingly to conventional missile strikes. Finally, we found that the participants in our nuclear and conventional conditions reported very similar concerns when they were considering the use of force in our scenarios, with the worry about civilian casualties and suffering of victims at the top of the list across experimental treatments.

Beyond the contribution to the scholarly literature on public attitudes to nuclear (non)use, these findings should be pertinent for policymakers in NATO countries. Earlier studies have shown that the Russian public tends to support the Kremlin's military adventurism (Kolesnikov 2016; Gudkov 2019), and, at the same time, sees the Russian nuclear arsenal as an increasingly important aspect of the country's great-power status (Wagner 2021). In this context, the complex nuclear modernization, saber-rattling, as well as the demise of the key pillars of arms control architecture have only reinforced Western fears that Russia is prepared to use nuclear weapons as a coercive tool in a future conflict on NATO's eastern flank. Our 
findings, however, suggest that if the Russian leadership would want to use nuclear weapons in a conflict with NATO, even in a very limited way as a demonstration of resolve, it would likely face a strongly disapproving domestic reaction. Obviously, this does not mean that public opinion would be the only (or even the most important) factor in Moscow's decision-making process regarding nuclear employment. Yet, as we discuss later in this paper, prior research has convincingly shown that public views on foreign policy do matter for elite decision-making in Russia - and, in fact, increasingly so. As such, a deeper understanding of public attitudes in Russia can be an important addition to our attempts to decipher Russian strategy through the reading of official documents and the ambiguous statements of Vladimir Putin and his decisionmaking circle.

We proceed as follows. First, we review existing expert accounts and public opinion polls on Russian views on nuclear weapons. Second, we formulate our theoretical expectations and hypotheses. Third, we introduce the experimental design for our study. Fourth, we present the results of our analyses. Fifth, we provide a broader discussion of the scholarly and policy implications of our findings. We conclude with a summary of findings and recommendations for further research.

\section{Russian views on nuclear weapons}

During the Cold War, Soviet citizens were mostly kept in the dark about developments in the nation's nuclear weapons policy. The image of a nuclear apocalypse was less present in the Russian national psyche than in the West, not least given the absence of "Soviet nuclear Armageddon stories" (Deriglazova \& Rozhanovskaya, 2020, p. 131). Particular aspects of the Soviet nuclear program were not a common subject of discussion among the public. This, however, changed after the dissolution of the Soviet Union, when defense matters, including nuclear policy, have become featured more frequently in the Russian news. As Kolesnikov (2016, p. 1) notes, "peddling threats, external and internal, including the threat of war, to the 
Russian people is a key tool of the Putin regime's political strategy.” Accordingly, the public views on these matters have gradually become a relevant factor in the decision-making of the leadership in Moscow (Zimmerman 2002).

Over the years, pollsters such as the Russian Public Opinion Research Center (VTsIOM) and the Levada Center have provided some limited insights into Russian views on nuclear weapons. First, there is a consistent finding that "Russians like their nuclear weapons" (Sokov, 2016, p. 204), mainly because the possession of a nuclear arsenal gives them a sense of security and importance (Akhtamzyan 2006). In longitudinal polling between 1999 and 2018, a growing share of the population considered "military might, including nuclear weapons" an attribute of Russian greatness (Levada Center 2019). The view that nuclear weapons are an indispensable aspect of Russian identity has been on the rise in the past two decades, with an increasing number of Russians who "see military strength and nuclear weapons as the main symbol of international prestige and pride" (Wagner, 2021, p. 162).

Second, Russians are fairly supportive of nuclear arms control and not particularly in favor of expanding their nuclear arsenal (Akhtamzyan 2006; Steinbruner and Gallagher 2008; Wagner 2021). Only about one third of Russians believes that nuclear weapons should target any particular state permanently (Akhtamzyan, 2006).

Third, Russians are only somewhat concerned about the threat of a nuclear war. In a 2006 poll, about $29 \%$ of respondents believed that it was likely that a foreign country would use nuclear weapons against Russia (Akhtamzyan, 2006). In a 2015 poll, about $13 \%$ of Russians reported fearing a nuclear war, yet more than half of them feared a war between Russia and NATO (Sokov, 2016). Positive views on nuclear weapons rose sharply after NATO's 1999 bombing of Yugoslavia (Deriglazova \& Rozhanovskaya, 2020). The United States remains seen as the largest nuclear threat after nuclear-armed terrorist groups (Akhtamzyan, 2006; Deriglazova \& Rozhanovskaya, 2020). 
To the best of our knowledge, there are no contemporary polls examining to what extent the Russian public would approve of the use of nuclear weapons in a conflict with NATO. While Russians have been increasingly supportive of their country's possession of nuclear weapons and see NATO as a major threat, it is not clear whether these attitudes translate to support for actual nuclear strikes. As Walker (2010) points out, there are distinct norms in world politics that regulate the possession and the use of nuclear weapons, and the aversion to the military employment of nuclear weapons does not preclude enthusiastic support for maintaining nuclear arsenals. Overall, our field lacks studies that would make an inquiry into the strength and the nature of "atomic aversion" in Russia - one of the gaps our paper is trying to fill.

\section{Theoretical expectations}

\section{Scenarios of nuclear use}

Our first aim in the experiment is to investigate the baseline difference in Russian public attitudes toward nuclear and conventional missile strikes. This will allow us to see to what extent Russians perceive the extraordinary nature of nuclear weapons when compared to attacks that are also strategic in their aims and would likewise result in a high number of casualties but are still perceived as "conventional" in the parlance of world politics. Building on Press, Sagan, and Valentino (2013), we expect that on average, Russian citizens will see the use of a nuclear weapon against a military target in a conflict with NATO significantly less approvingly than the use of conventional missiles. Even if these attitudes do not correspond to a full-fledged "unthinkable" taboo shared by virtually everyone, we believe that most citizens would see the use of nuclear weapons as an extreme, last measure option that would be considerably less approved of than conventional strikes absent of the corresponding stigma. 


\section{$\Longrightarrow H_{1}$ : Other things being equal, Russian citizens are more averse to the limited use of nuclear weapons in a military conflict with NATO than to the use of conventional missiles.}

Another aim of our experiment is to examine the elasticity of Russian views when a nuclear strike is stripped of its main negative side effects - that is, the dramatic loss of civilian life. In line with the findings of Bowen, Goldfien, and Graham (2021), we would expect that the public aversion to nuclear use would be significantly reduced under these conditions. It is, however, also possible that large swaths of the public see nuclear use as unequivocally wrong under any circumstances, and would not, therefore, become more accepting of nuclear use even when these negative characteristics disappear.

In the U.S. context, there were so far mixed findings on the elasticity on public views with respect to civilian deaths. In Sagan and Valentino (2017), there was no significant change in support for nuclear strikes between conditions that described 100,000 and 2 million civilian fatalities. Haworth, Sagan, and Valentino (2019) similarly found that strikes resulting in 15,000 and 1 million fatalities saw a comparable level of public support. However, Koch and Wells (2020) found that vivid information about the harm to civilians that results from a nuclear strike decreases public support. Similarly, Smetana and Vranka (2021) found that a higher number of civilian fatalities lowers both the approval of and preference for nuclear use.

With respect to the real-world relevance of our inquiry, Russian strategic thinking indeed envisages the possibility of conducting a purely demonstrative nuclear strike that would result in no (or very few) casualties and would have no (or very little) direct operational impact on the battlefield situation (Johnson 2018). Some analysts, therefore, suggest that rather than using nuclear weapons against NATO assets, Russia might consider demonstratively exploding a nuclear weapon in an unpopulated area as an alternative form of coercive pressure (Luik and 
Jermalavicius 2017; Kühn 2018). If the Kremlin believes that such a nuclear demonstration would be significantly more acceptable for the relevant audiences (including the Russian public) than a direct strike against a military target, it might be particularly tempted to explore this option in a conflict with NATO.

\section{$\Longrightarrow \mathrm{H}_{2}$ : Other things being equal, Russian citizens are more averse to the use of a nuclear weapon against a NATO military target than a demonstrative nuclear explosion in an unpopulated area.}

We can also gain another important insight into the elasticity of Russian views by comparing the level of public support for nuclear use under different levels of conflict intensity - that is, to examine whether we can see a significant shift in attitudes when there is a recognizable shift in the conflict escalation. In the U.S. context, Haworth, Sagan, and Valentino (2019) found that the escalation of the situation (a North Korean attack on a U.S. ship, in addition to a long-range nuclear missile test) does significantly increase public support for a U.S. nuclear strike against North Korea. In a partial replication of Sagan and Valentino (2017), Smetana and Vranka (2021) found that a higher number of expected fatalities among American troops drives the support for nuclear use up. Our scenarios would, therefore, accordingly test for the elasticity of public support in a higher-stakes conflict situation.

Understanding public support for nuclear use under different escalation scenarios carries potentially very important strategic implications. Some experts on Russian nuclear strategy argue that Moscow's actual threshold for using nuclear weapons has been ambiguous (Fink 2017). In line with the latest formulation of the Russian deterrence doctrine (Putin 2020), Moscow might refrain from nuclear strikes in a limited conflict outside of its borders but resort to nuclear use once the Russian territory proper comes under attack. If the Kremlin believes that direct attacks on Russian soil make the use of nuclear weapons significantly more justified 
in the eyes of the public, it may perceive less of a normative barrier to conduct a nuclear strike on the higher rung of the escalation ladder.

$\Longrightarrow H_{3}$ : All things being equal, Russian citizens are more averse to the use of nuclear weapons in a limited military conflict with NATO outside of Russian borders than in an escalated conflict where the Russian territory is under attack.

\section{Moral foundations and (non-)use attitudes}

Another aim of our survey experiment in Russia is to follow up on the recent research in the United States that demonstrated the relationship between individuals' moral values and their support for nuclear strikes (Rathbun and Stein 2020; Smetana and Vranka 2021). These studies draw on the Moral Foundations Theory (MFT), which identifies building blocks of morality shared by individuals across cultures: prevention of harm and caring for the vulnerable (care/harm), fairness and reciprocity (fairness/cheating), loyalty to one's in-group (loyalty/betrayal), respect for authorities and social hierarchies (authority/subversion), and maintenance of purity and avoidance of social contamination (sanctity/degradation) (Graham et al. 2013). While these five moral foundations are supposedly universal, their relative importance varies both within and across cultural domains. Research in moral psychology (Graham, Haidt, and Nosek 2009; Graham et al. 2011) suggests that while the first two "individualizing foundations" correspond to the liberal understanding of morality in the West, many non-Western cultures have also strongly relied on the remaining three "binding foundations", which are associated with attitudes and behaviors benefiting larger (in-)groups as opposed to individuals (Haidt and Joseph 2004).

According to Rathbun and Stein $(2020,796)$, "[n]uclear weapons are symbols as well as explosive devices, and their symbolism should increase their perceived utility when seen through the lens of nonliberal ethical values [...] in contrast, the symbolic qualities of nuclear 
weapons should be repellent from the perspective of the individualizing foundations, which emphasize the rights and well-being of others." In the U.S. setting, individualizing foundations were indeed associated with a higher aversion to nuclear strikes and binding foundations with a lower aversion to these strikes. A study of Russian attitudes can reveal to what extent these associations are culturally-specific to the United States as a Western country or if they similarly hold in non-Western Russia.

\footnotetext{
$\longrightarrow \quad H_{4}:$ Russian citizens' individualizing moral foundations are associated with higher aversion to the use of nuclear weapons.

$\longrightarrow \quad H_{5}:$ Russian citizens' binding moral foundations are associated with lower aversion to the use of nuclear weapons.
}

However, Smetana and Vranka (2021) also found that there was no significant interaction between the type of strike and moral foundations in their study of U.S. attitudes. As such, they note that they "did not find any evidence of any specific moral foundations-related barriers connected with the use of nuclear or chemical weapons, suggesting that the public does not necessarily separate them as a qualitatively distinct category of immoral weapons" (Smetana and Vranka 2021, 385). Drawing on these findings, we formulate the following hypothesis to test whether we can see a similar pattern in the study of Russian attitudes.

$\Longrightarrow \quad H_{6}$ : There is no significant interaction between Russian citizens' moral foundations and the type of weapon used in a military strike.

\section{Reasoning behind strike (dis-)approval}

The exploratory part of our survey will examine the self-reported reasoning of our participants behind their approval or disapproval of the strikes in our scenarios. To allow a systematic 
categorization, we have opted against open-ended responses. Instead, we have decided to provide a set of possible concerns, allowing our respondents to indicate how important each was for them. Building on Press, Sagan, and Valentino (2013), we include concerns about the international reputation of the perpetrator and the setting of a dangerous precedent that would make other countries more likely to use nuclear weapons in the future, as well as the concern that nuclear use is immoral and results in too many civilian casualties.

In addition to these concerns that reflect the theoretical debates between the "nonuse tradition" (Sagan 2004; Paul 2009) and the "nuclear taboo" literature (Tannenwald 2007), we added some additional concerns that are commonly discussed in nuclear weapons scholarship and could be possibly relevant in our respondents' reasoning. Some individuals may be particularly concerned about nuclear retaliation or conventional retaliation, in line with literature that identifies nuclear (Jervis 1984; Waltz 1981) or conventional (Ludvik 2019; Sherrill 2018) deterrence as the key causal factor in nonuse decisions. In addition to the concern about civilian casualties, some individuals may also be concerned about other negative side effects of nuclear use, such as too many enemy casualties or environmental destruction (Bowen, Goldfien, and Graham 2021). The concerns that any use of nuclear weapons is incompatible with international law and would cause great suffering to individuals are today at the forefront of the Humanitarian Initiative to ban nuclear weapons globally (Borrie 2014). The retribution motive corresponds to the concern that the enemy deserves to be punished for its actions (Sagan and Valentino 2017; Rathbun and Stein 2020). Finally, some individuals might be concerned that the use of nuclear weapons is meaningless because it would have no effect on what the enemy does (Mueller 2012). 


\section{Experimental design}

We designed a survey experiment fielded to a representative sample of Russian adult citizens by IPSOS, a leading polling company, between May 13 and 25, 2021. Our sample consisted of 1,507 participants, approximating the population of the Russian Federation in gender, age, and regional diversity. Our sample includes both supporters of the current leadership in Moscow and its opponents, with most respondents positioned somewhere in the middle of the scale and $15 \%$ of respondents strongly disapproving of the Russian regime. The survey consisted of eight parts: 1) socio-demographic items; 2) the Moral Foundations Questionnaire (MFQ); 3) a vignette with one of the versions of the scenario; 4) questions about strike approval; 5) evaluation of individual concerns; 6) questions about strike preference; 7) questions about leadership approval and attitudes toward other countries; 8) survey debrief. ${ }^{3}$

To investigate the public support for nuclear strikes under different experimental conditions, we randomly divided our participants into four treatments. The participants read a vignette with one of the versions of a fictional scenario describing protests of the Russian minority in Latvia that had been violently suppressed by the Latvian army. To protect the Russian minority, the Russian army crossed the borders and occupied the Latgale region, leading Riga to invoke Article V and asking NATO allies for military assistance. The first wave of NATO forces then clashed with the Russian army at Latgale's western borders, with heavy losses on both sides after several days of fighting.

Further description of the scenario then differed across treatments. In condition A (the “limited nuclear" condition), Russian generals proposed to use a single nuclear weapon against a NATO military base in Poland to demonstrate Russian resolve and force NATO

\footnotetext{
${ }^{3}$ See Appendix 1 for the socio-demographical composition of our sample and Appendix 2 for all survey items and scenarios.
} 
representatives to meet with their Russian counterparts and negotiate peace terms favorable to Moscow. On one hand, we noted that without this nuclear strike, Russia would risk a humiliating defeat, would have to withdraw its forces, and leave the Russian minority in Latvia to its fate. ${ }^{4}$ On the other hand, the strike would likely result in a high number of deaths among NATO soldiers and Polish civilians as collateral damage. The condition B (the "limited conventional" condition) was identical, except that 50 conventional missiles were proposed instead of a single nuclear weapon against the base ${ }^{5}$ Condition C (the "demonstrative nuclear" condition) was identical to A, except that the generals proposed to explode a nuclear weapon in an unpopulated area in the North Sea instead of using it against the NATO base (as such, there was no anticipation of collateral damage). Finally, the condition D (the "escalated nuclear" condition) was identical to A, except the original conflict situation has escalated further: the

\footnotetext{
${ }^{4}$ Our choice of words was meant to highlight the high-stakes nature of the situation, to prevent an impression that this was a merely a minor regional issue where the consideration of nuclear use would be completely unrealistic. We added the adjective "humiliating" to stress the prestige/status aspect of the great-power conflict, something potentially quite relevant with respect to (pro-)nuclear attitudes given that Russians generally "see military strength and nuclear weapons as the main symbol of international prestige and pride” (Wagner, 2021, p. 162). Similarly, with the note about leaving "the Russian minority in Latvia to its fate," we wanted to stress that there would be tangible consequences of non-action, highlighting the discourse on "protecting Russian minorities abroad" that is frequently employed by the current leadership in Moscow and that would certainly be on repeat in Russian media should such a crisis develop in real life. It is important to stress that while there are certainly many ways of formulating the scenario, our findings demonstrate that even a very substantive change in the text of the experimental treatment (e.g., the difference between conditions $\mathrm{A}$ and $\mathrm{C}$ or $\mathrm{A}$ and D) did not shift the public support for nuclear use, suggesting that minor wording changes would like to have null effect as well.

${ }^{5}$ In setting the number of conventional missiles in this treatment, we followed Press, Sagan, and Valentino (2013), who compared the use of 100 conventional missiles with the use of 2 nuclear missiles.
} 
subsequent wave of NATO forces reclaimed Latgale, pushed Russian forces out of Latvia, and launched missile strikes against targets in Russian territory.

Following earlier nuclear nonuse experiments, we were interested in examining both our participants' approval of these strikes and their preference for the strike with respect to an alternative method of the use of force. For the approval part, the participants indicated how much they would agree or disagree with the strike described in the scenario on a six-point Likert scale from 1-strongly agree to 6-strongly disagree. For the preference part, we asked whether they would prefer an alternative method of strike if they were to choose; in A, B, and D, they chose between using a single nuclear weapon or 50 conventional missiles, in $\mathrm{C}$, they chose between a nuclear strike against a NATO base and a demonstrative nuclear explosion over the North Sea.

For our inquiry into the relationship between moral foundations and strike approval, our participants filled in the MFQ, a standardized survey tool to measure individuals' scores in five moral foundations (Graham et al. 2011). ${ }^{6}$ To control for potentially confounding variables, we also added some additional survey items that we would later include in the regression analysis. In line with earlier nuclear nonuse scholarship, we included questions about gender, age, income, and education as standard socio-demographic measures. We did not include the usual questions about our participants' political affiliation, given that Russia is a country that does not allow for free and democratic competition among independent political parties. Instead, we asked the participants about their approval of the leadership of Russia on a five-point scale from 1-strongly disapprove to 5-strongly approve. Moreover, we asked how "cold" or "warm" the participants felt toward several countries (the United States, Poland, Latvia, the Czech Republic, the Netherlands, China, and Ukraine) on a slider from 0 ("coldest") to 10

\footnotetext{
${ }^{6}$ The MFQ, including a Russian translation, is available at https://moralfoundations.org.
} 
("warmest"). While we were primarily interested in attitudes toward Poland, as a country that hosted the targeted NATO base in our scenario, we included several other countries to detract attention from Poland specifically and limit the priming effect by the preceding scenario.

To examine the relative importance of individual concerns, we asked the participants about the reasoning behind their agreement or disagreement with the strike and asked them to evaluate twelve concerns on a five-point scale from 1-not at all important to 5-very important. In contrast to Press, Sagan, and Valentino (2013), we asked about the concerns regarding the strike approval rather than preference for the strike in relation to the alternative type of strike. We believe that both approaches provide interesting but qualitatively distinct insights into the nature of "atomic aversion". While the former primes the respondent to think about the differences between two weapon types, the latter allows us to identify the more general concerns about the strike itself rather than the strike in relation to an alternative method of warfare. Since we asked the same set of questions across conditions, we were able to compare directly the concerns of individuals in both nuclear and conventional treatments. We also let our respondents indicate the relative importance of all concerns rather than selecting the single most important concern as in Press, Sagan, and Valentino (2013), which arguably allowed us to provide a more plastic picture of individuals' reasoning in such a complex matter.

After the participants finished the survey, they read a short debrief section where we explained our research aims and stressed that we did not argue for the use of any kind of weapon and that we were aware that the scenario did not cover the full spectrum of aspects and considerations that would be important in real life. We also stressed that any use of force must obey the law of war (jus in bello), where the key principles are military necessity, distinction, and proportionality. This debriefing item was meant to counteract possible conditioning effects of our experiment, in line with recent calls for a more responsible approach to public opinion surveys portraying the use of military force (Carpenter, Montgomery, and Nylen 2020). 


\section{Results}

Strike approval and preference between conditions

In the data analysis, we first compared the level of approval in "limited nuclear" (A) and "limited conventional" (B) treatments. Following Press, Sagan, and Valentino (2013), we dichotomized the participants' approval made on a six-point scale to 0 ("approve") and 1 (“disapprove"). As shown in Figure 1, 45\% of participants approved of a conventional strike and 55\% disapproved. However, for a nuclear strike, approval dropped to $27 \%$ and disapproval rose to $73 \%$. The difference between the conditions was statistically significant $\left(\chi^{2}(1)=26.7, p\right.$ $<.001)$.

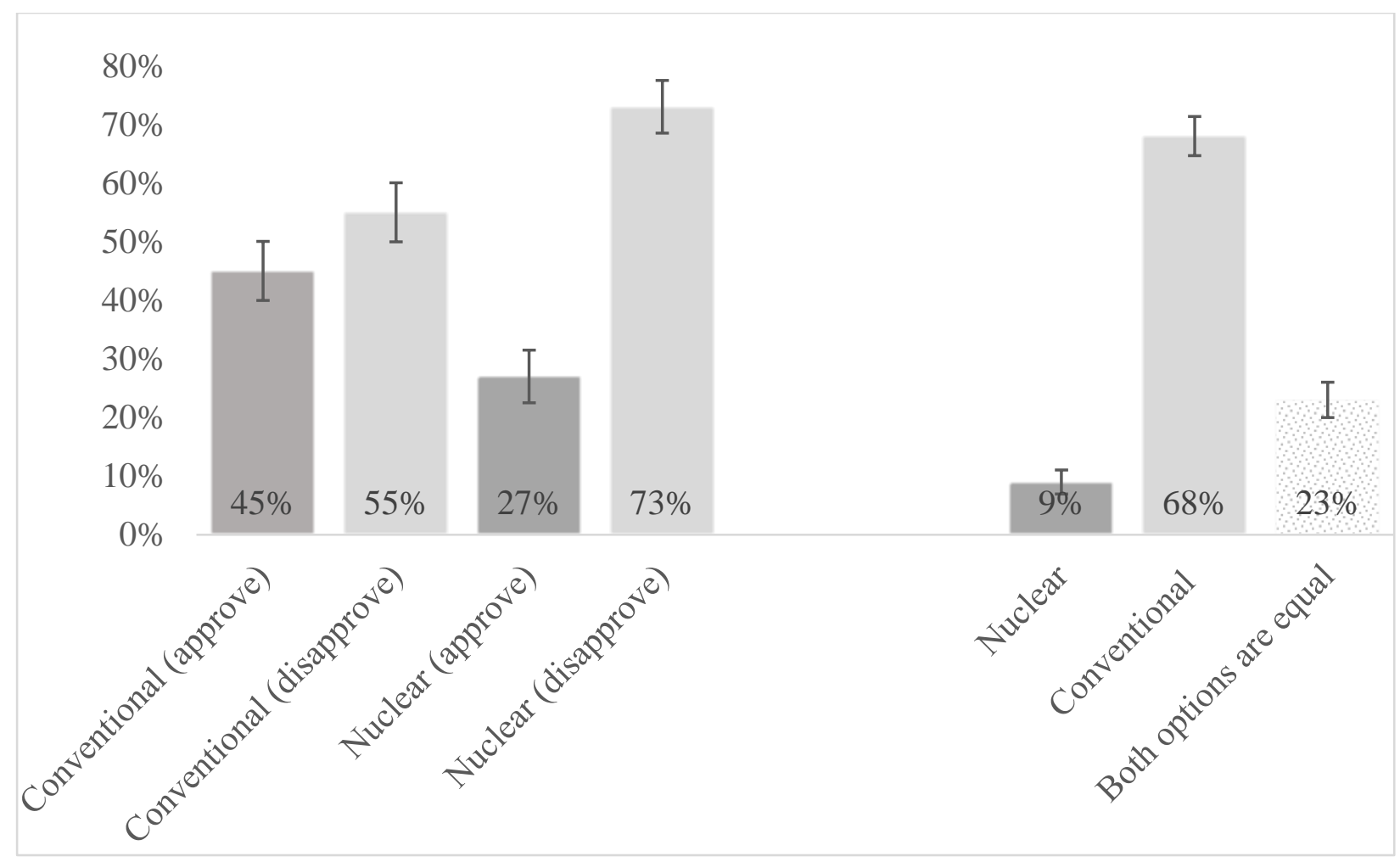

Figure 1. Approval of and preference for conventional and nuclear strikes. Error bars are $95 \%$ confidence intervals. $N=750$.

Next, we examined the preferences of our participants once they were asked whether they would choose a nuclear or a conventional strike. Figure 1 shows that $9 \%$ of participants preferred the nuclear option, $68 \%$ preferred the conventional option, and for $23 \%$, both options 
were equal. All differences were significant at $p<.001$. As such, we gain empirical support for our hypothesis $H_{1}$ that Russian citizens are more averse to the limited use of nuclear weapons in a military conflict with NATO than to the use of conventional missiles.

We repeated the same procedure for the treatments involving a nuclear strike against a NATO base (A) and a demonstrative nuclear explosion in an unpopulated area in the North Sea (C). As we show in Figure 2, the level of approval was identical in both treatments $\left(\chi^{2}(1)=\right.$ $0.0019, p=0.965): 27 \%$ of respondents agreed with nuclear use and $73 \%$ disagreed.

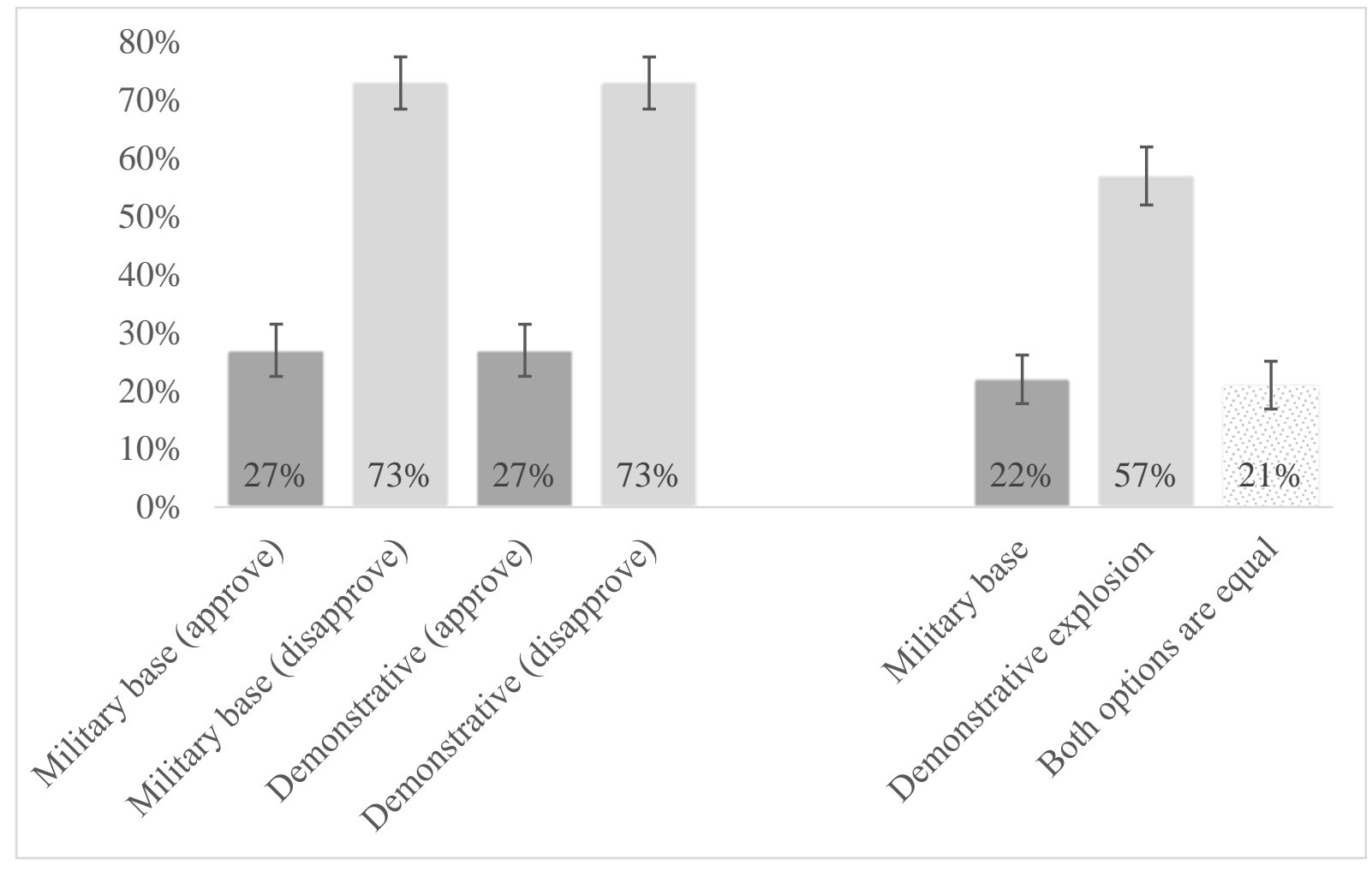

Figure 2. Approval of and preference for a nuclear strike against a military base and a demonstrative nuclear explosion. Error bars are 95\% confidence intervals. $N($ approval $)=752, N($ preference $)=377$.

Yet, Figure 2 also shows a clear preference for a demonstrative explosion once the participants were provided with both options: $57 \%$ preferred the demonstrative explosion, $22 \%$ the strike against the military base, and $21 \%$ saw both options as equal. The difference between the demonstrative option and the two remaining options was statistically significant $\left(\chi^{2}(2)=59.3\right.$, $p<.001)$. As such, we gain only partial empirical support for $H_{2}$ : while the strike approval in 
the two conditions was identical, if given a choice between the two options, Russians clearly prefer a demonstrative strike over a direct attack against a military target.

Finally, we repeated the same procedure to compare the level of strike approval in the original "limited conflict" scenario (A) and in a more pressing "escalated conflict" scenario (D). As we show in Figure 3, the nuclear strike in a limited scenario was only slightly less approved $(27 \%)$ than in an escalated scenario (29\%). The difference was not statistically significant $\left(\chi^{2}(1)=0.47, p=0.492\right)$.

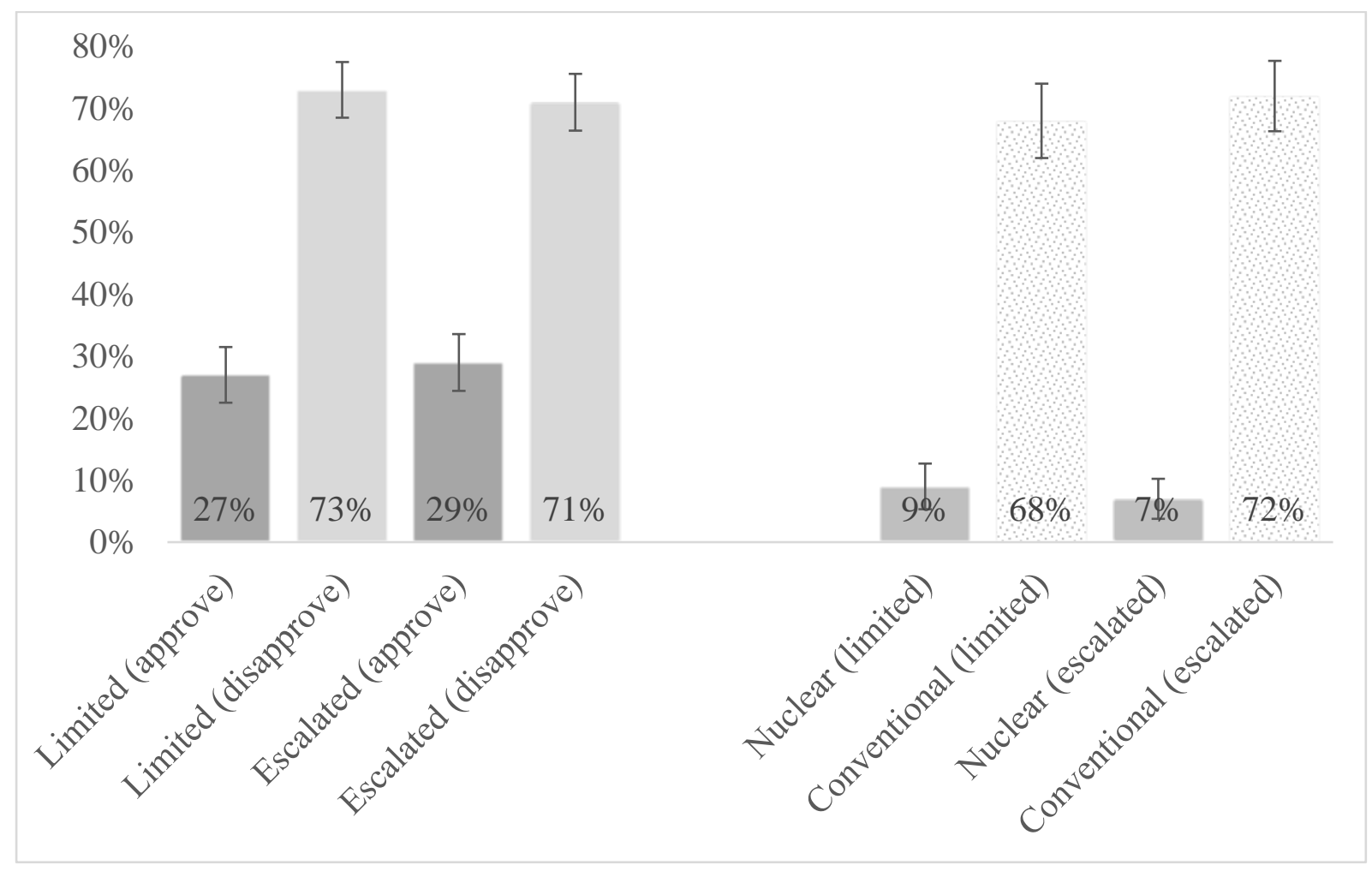

Figure 3. Differences in approval of and preference for a nuclear strike in limited and escalated scenarios.

Error bars are 95\% confidence intervals $(\mathrm{CI}) . N($ approval $)=752, N($ preference $)=472$.

As for strike preference, in a limited scenario A, $9 \%$ of participants preferred the nuclear option, $72 \%$ preferred the conventional option, and for $19 \%$, both options were equal. In an escalated scenario D, $7 \%$ preferred nuclear, $68 \%$ conventional, and $25 \%$ either option. The difference in strike preferences between scenarios A and D was not statistically significant $\left(\chi^{2}(2)=2.46, p=\right.$ 
0.293). As such, we did not gain empirical support for $H_{3}$ that Russian citizens are more averse to the use of nuclear weapons in a limited military conflict with NATO outside of Russian borders than in an escalated conflict where the Russian territory is under attack.

\section{Regression analysis}

Next, we conducted a binominal logistic regression with approval (0) or disapproval (1) of a military strike as a dependent variable. In Model 1a, we included the basic sociodemographic variables (gender, age, education, and income) and the experimental condition (nuclearconventional) as predictors. As we show in Table 1, the regression coefficients for the type of weapon used in the strike remained significant. Moreover, the model shows that female respondents judged the use of a military strike less approvingly than male respondents. Other sociodemographic predictors were not significantly related to strike approval.

To see whether the effects of sociodemographic predictors are associated with the specific type of strike, we examined the interaction between the condition and other predictors (Model 1b). Our findings show that there is a significant interaction between gender and the type of strike: women are, on average, more averse to the use of any kind of military strike than men, but this difference is particularly large in the conventional domain. In the nuclear domain, the attitudes of women and men become more similar. We also found a reverse dynamic related to income: participants with a lower monthly income than 30,000 RUB (approximately $\$ 400$ ) were more supportive of nuclear use than those with a higher income, while the attitudes are reversed in the conventional scenario. Model $1 \mathrm{~b}$ fitted the data significantly more $\left(\chi^{2}(4)=9.67\right.$, $p=0.046)$, than the previous Model 1a without the interaction terms. 
Table 1. Approval of a military strike (logit)

\begin{tabular}{|c|c|c|c|c|c|}
\hline & Model 1a & Model 1b & Model 2a & Model 2b & Model 3 \\
\hline Predictor & $\begin{array}{l}\text { Coef. } \\
\text { (SE) }\end{array}$ & $\begin{array}{l}\text { Coef. } \\
\text { (SE) }\end{array}$ & $\begin{array}{c}\text { Coef. } \\
\text { (SE) }\end{array}$ & $\begin{array}{c}\text { Coef. } \\
\text { (SE) }\end{array}$ & $\begin{array}{c}\text { Coef. } \\
\text { (SE) }\end{array}$ \\
\hline Condition (nuclear - conventional) & $\begin{array}{c}0.778 * * * \\
(0.126)\end{array}$ & $\begin{array}{c}-1.125 * * * \\
(0.151)\end{array}$ & $\begin{array}{c}0.825 * * * \\
(0.130)\end{array}$ & $\begin{array}{c}0.088 \\
(0.677)\end{array}$ & $\begin{array}{c}0.820 * * * \\
(0.132)\end{array}$ \\
\hline Gender (female - male) & $\begin{array}{c}0.512 * * * \\
(0.120)\end{array}$ & $\begin{array}{c}0.983 * * * \\
(0.232)\end{array}$ & $\begin{array}{c}0.428 * * * \\
(0.123)\end{array}$ & $\begin{array}{c}0.437 * * * \\
(0.124)\end{array}$ & $\begin{array}{c}0.381 * * \\
(0.127)\end{array}$ \\
\hline Age & $\begin{array}{c}0.126 \\
(0.067)\end{array}$ & $\begin{array}{c}0.093 \\
(0.131)\end{array}$ & $\begin{array}{c}0.106 \\
(0.069)\end{array}$ & $\begin{array}{c}0.109 \\
(0.069)\end{array}$ & $\begin{array}{l}0.168 * \\
(0.071)\end{array}$ \\
\hline College education & $\begin{array}{c}0.162 \\
(0.122)\end{array}$ & $\begin{array}{c}-0.004 \\
(0.230)\end{array}$ & $\begin{array}{c}0.153 \\
(0.124)\end{array}$ & $\begin{array}{c}0.151 \\
(0.125)\end{array}$ & $\begin{array}{c}0.197 \\
(0.127)\end{array}$ \\
\hline Income (monthly > 30k RUB) & $\begin{array}{c}-0.055 \\
(0.121)\end{array}$ & $\begin{array}{c}0.390 \\
(0.227)\end{array}$ & $\begin{array}{l}-0.046 \\
(0.123)\end{array}$ & $\begin{array}{c}-0.042 \\
(0.124)\end{array}$ & $\begin{array}{c}-0.048 \\
(0.126)\end{array}$ \\
\hline Condition $*$ Gender & - & $\begin{array}{c}-0.653 * \\
(0.272) \\
\end{array}$ & - & - & - \\
\hline Condition * Age & - & $\begin{array}{c}0.034 \\
(0.153)\end{array}$ & - & - & - \\
\hline Condition $*$ College education & - & $\begin{array}{c}0.231 \\
(0.272)\end{array}$ & - & - & - \\
\hline Condition * Income & - & $\begin{array}{l}-0.626^{*} \\
(0.269)\end{array}$ & - & - & - \\
\hline Individualizing foundations (IF) & - & - & $\begin{array}{c}0.881 * * * \\
(0.125)\end{array}$ & $\begin{array}{c}0.849 * * * \\
(0.224)\end{array}$ & $\begin{array}{c}0.716 * * * \\
(0.131)\end{array}$ \\
\hline Binding foundations (BF) & - & - & $\begin{array}{c}-0.570 * * * \\
(0.126)\end{array}$ & $\begin{array}{c}-0.711 * * \\
(0.231)\end{array}$ & $\begin{array}{c}-0.286^{*} \\
(0.141)\end{array}$ \\
\hline Condition * IF & - & - & - & $\begin{array}{c}0.044 \\
(0.269)\end{array}$ & - \\
\hline Condition * BF & - & - & - & $\begin{array}{c}0.196 \\
(0.274)\end{array}$ & - \\
\hline Attitude toward Poland & - & - & - & - & $\begin{array}{c}0.118 * * * \\
(0.022)\end{array}$ \\
\hline Leadership approval & - & - & - & - & $\begin{array}{c}-0.211 * * * \\
(0.054)\end{array}$ \\
\hline Intercept & $\begin{array}{l}-0.566^{*} \\
(0.287)\end{array}$ & $\begin{array}{l}-0.849 \\
(0.534)\end{array}$ & $\begin{array}{c}-1.825 * * * \\
(0.397)\end{array}$ & $\begin{array}{c}-1.309 * \\
(0.609)\end{array}$ & $\begin{array}{c}-2.127 * * * \\
(0.440)\end{array}$ \\
\hline Model fit $\left(\mathrm{R}^{2} \mathrm{McF}\right)$ & 0.034 & 0.039 & 0.063 & 0.064 & 0.091 \\
\hline
\end{tabular}

$* p<0.05, * * p<0.01, * * * p<0.001$ 
In the next step, we tested our hypotheses concerning the association between support for military strikes and moral values. In line with Rathbun and Stein (2020), we reduced the five MFQ variables to two higher order factors: "individualizing foundations" (IF), averaging scores from care/harm and fairness/cheating subscales, and "binding foundations" (BF), averaging loyalty/betrayal, authority/subversion, and sanctity/degradation. The mean score of our participants' IF was 3.5, whereas the mean score of BF was 2.99, in line with other studies of moral foundations in non-Western countries. ${ }^{7}$

We included IF and BF as additional predictors to Model 1a. The resulting Model 2a shows that they were both significantly associated with the approval of military strikes: in line with our hypotheses, the participants who scored high on IF were less likely to agree with the strike $\left(H_{4}\right)$ and those who scored high on BF were more likely to agree $\left(H_{5}\right)$. Model 2 a fitted the data significantly more $\left(\chi^{2}(2)=54.07, p<0.001\right)$ than the previous Model 1a without the moral foundations.

Model $2 \mathrm{~b}$ then shows that there were no significant interactions between the moral foundations and the experimental condition, suggesting that moral foundations are associated with a general level of support for military strikes irrespective of whether they are nuclear or conventional. We, therefore, gain empirical evidence for $H_{6}$ : while IF are associated with higher aversion to nuclear use and higher scores in BF with lower aversion, these associations are not nuclear weapons-specific and similarly apply to the conventional strike condition.

\footnotetext{
${ }^{7}$ Note that some MFQ studies use a 1-6 scale rather than a 0-5 scale. If we had used the former, the mean score would be 4.5 for IF 3.99 for BF. This is in line with Dogruyol, Alper, and Yilmaz (2019), who found that the mean scores in WEIRD (Western, Educated, Industrialized, Rich, and Democratic) countries are 4.91 (IF) and 3.94 (BF), whereas in non-WEIRD countries 4.63 (IF) and 3.96 (BF).
} 
Finally, we further expanded the model with moral foundations (2a) by including two additional predictors: "warmness" toward Poland, as a country that was the target of the strike; and approval of the leadership of Russia, which would necessarily decide on the conduct of the strike. As we show in Model 3, both these factors were statistically significant: a "warmer" attitude toward Poland reduces the likelihood of support for military strikes, while a higher approval of the Russian leadership increases it. The inclusion of these two new variables reduced the regression coefficient of $\mathrm{BF}$ (which can be explained by the leadership approval logic partially driving the authority dimension of the "binding" morality), but both IF and BF remained statistically significant in the model. Finally, age became significant in Model 3, with older participants being more averse to the use of military strikes. Altogether, Model 3 fitted the data significantly more $\left(\chi^{2}(2)=51.0, p<0.001\right)$ than the previous Model 2a.

Table 2 sums up the results with respect to each hypothesis, with yes/no indicating whether we found empirical evidence in support of the hypothesis (separately for approval and preference tests).

\begin{tabular}{|c|c|c|c|c|}
\hline$H_{x}$ & Hypothesis & Conditions & Approval & Preference \\
\hline$H_{1}$ & $\begin{array}{l}\text { more averse to the limited use of nuclear weapons than } \\
\text { conventional missiles }\end{array}$ & $A-B$ & Yes & Yes \\
\hline $\mathrm{H}_{2}$ & $\begin{array}{l}\text { more averse to nuclear use against a military target than a } \\
\text { demonstrative nuclear explosion }\end{array}$ & $A-C$ & No & Yes \\
\hline $\mathrm{H}_{3}$ & $\begin{array}{l}\text { more averse to nuclear use in a limited conflict than in an } \\
\qquad \text { escalated conflict }\end{array}$ & $A-D$ & No & No \\
\hline$H_{4}$ & $\begin{array}{c}\text { individualizing moral foundations associated with higher } \\
\text { aversion to nuclear use }\end{array}$ & All & Yes & - \\
\hline $\mathrm{H}_{5}$ & $\begin{array}{l}\text { binding moral foundations associated with lower aversion } \\
\text { to nuclear use }\end{array}$ & All & Yes & - \\
\hline$H_{6}$ & $\begin{array}{l}\text { no interaction between moral foundations and the weapon } \\
\text { type }\end{array}$ & All & Yes & - \\
\hline
\end{tabular}

Table 2. Empirical support for each hypothesis (summary results). 
Reasoning behind strike (dis-)approval

In the final part of our analysis, our aim was to map the self-reported reasoning and the specific concerns of our participants when they were deciding on whether to approve or disapprove of the strikes described in the vignette. We centered the ratings of the importance of the concerns by subtracting the mean rating for the given participant from the rating of each concern. Figure 4 shows the concerns for all participants in a descending order, with the concern about civilian casualties being rated as the most important on average. There were no statistically significant differences between nuclear and conventional conditions, suggesting that individuals generally share a similar order of relevant concerns when they are considering the use of force in a military conflict, the type of weapon notwithstanding (see Appendix 3 for a more detailed analysis).

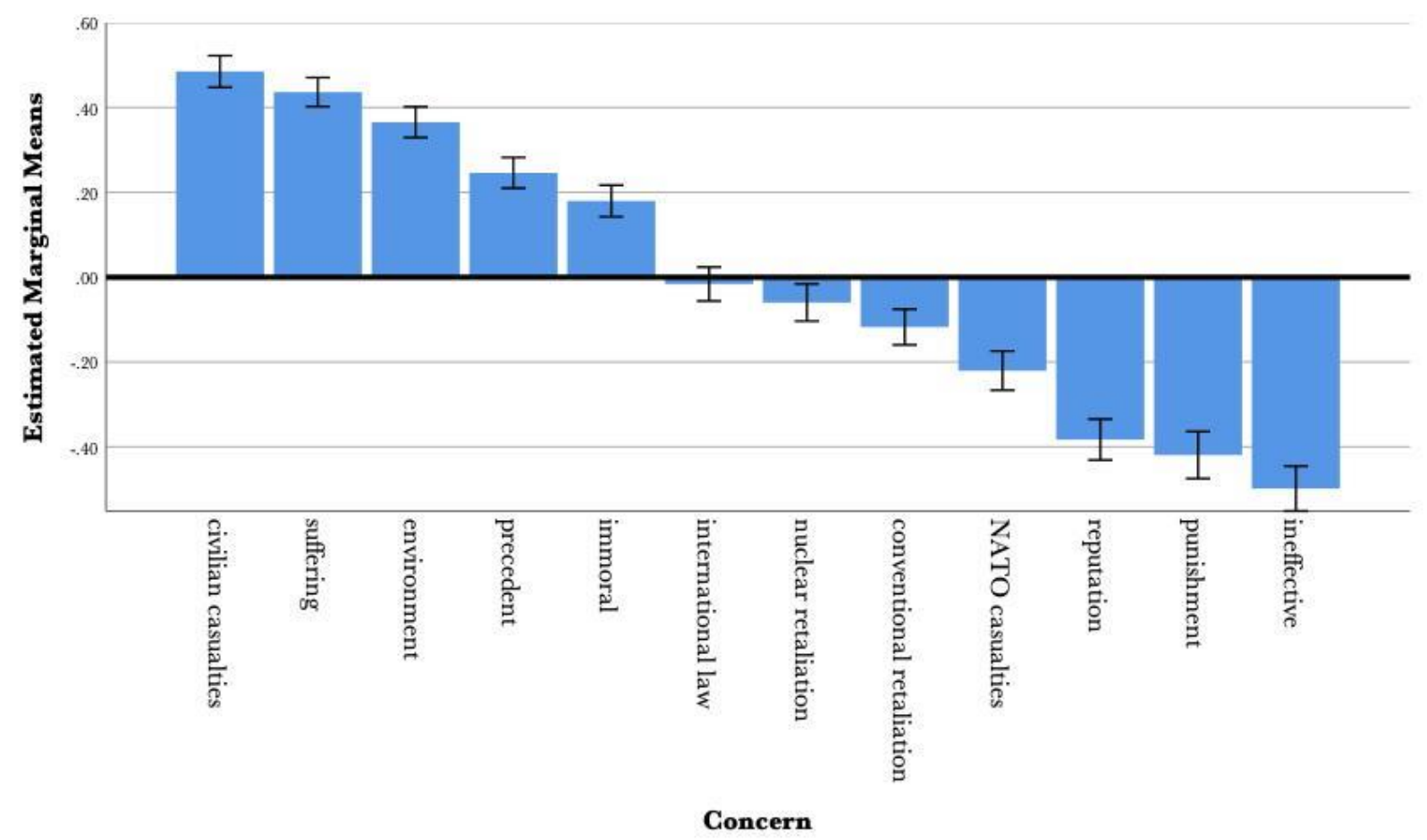

Figure 4. Relative importance of concerns across conditions. Error bars are $95 \%$ confidence intervals. $N=$ 1,507 . 
Figure 5 shows the differences between those who approved of and those who disapproved of nuclear use in our experiment. For both groups, the concern for civilian casualties was still a dominant one, although it was clearly stronger for those who disapproved of the strikes. There were also more pronounced differences: those who approved of the strikes were more concerned about both nuclear and conventional retaliation, about Russia's international reputation, the effectiveness of the strike, and the desire to punish NATO forces for their actions. Those who disapproved of the strikes, on the other hand, were more concerned about NATO casualties, about the breaking of a precedent, about the immorality of the strikes, international law, impact on the environment, and the victims' suffering.

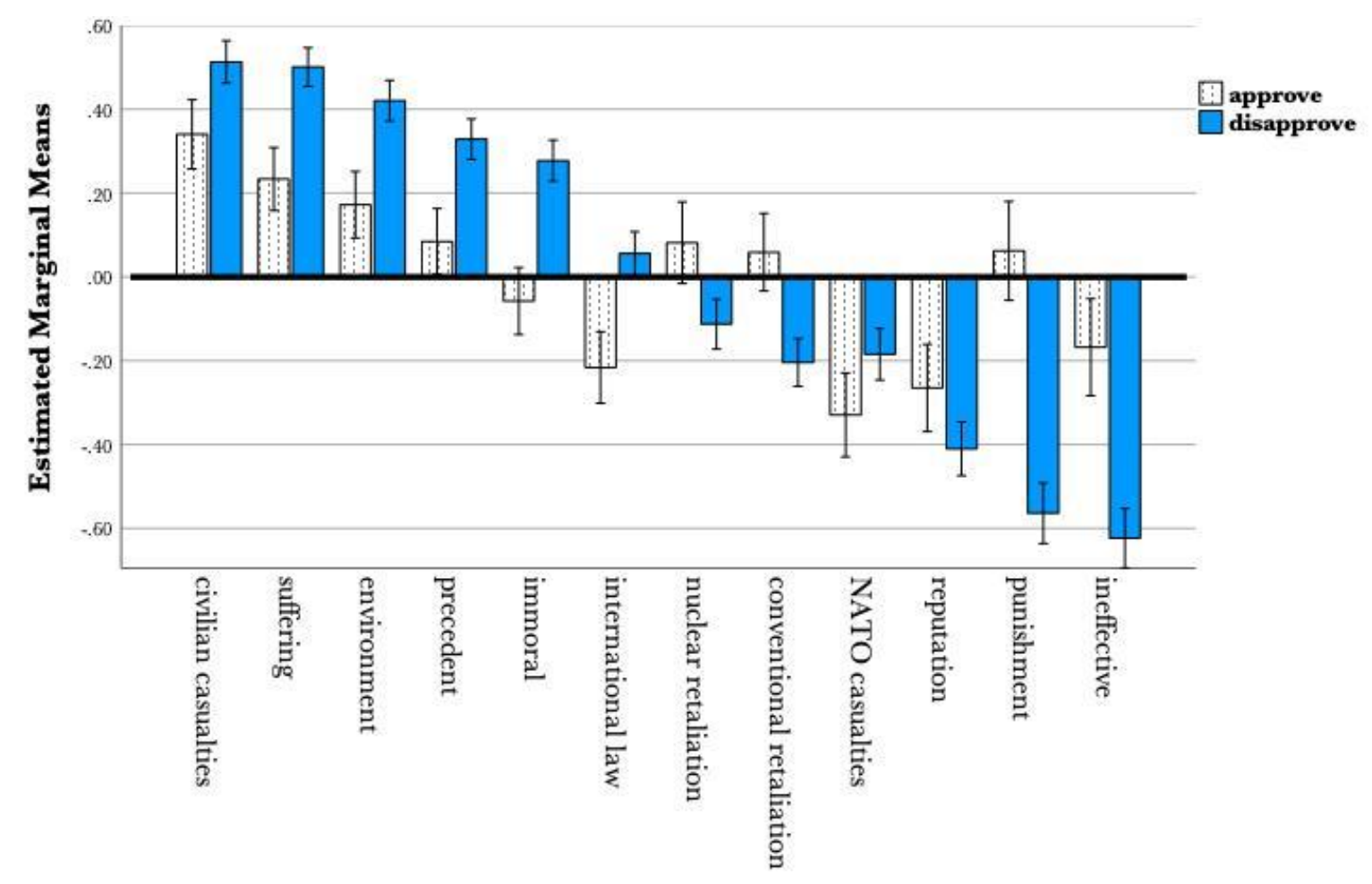

Concern

Figure 5. Relative importance of concerns for those who approved of and those who disapproved of the use of nuclear weapons. Error bars are 95\% confidence intervals. $N=1,129$. 


\section{Discussion}

If "Russians like their nuclear weapons," as Sokov (2016, p.204) claims, they certainly like much less the idea of their military use. Our findings suggest that a significant majority of Russian citizens would disagree with a limited "de-escalation" nuclear strike in a conflict with NATO even when such a move would help Moscow to avert defeat. The data show that this is not merely a principled pacifist stance; when dozens of conventionally-armed missiles were proposed for an analogous strike on a NATO base, almost half of our participants agreed with it. Only a very small fraction (less than $10 \%$ in every condition) of our respondents would prefer the nuclear over the conventional option if given the choice. These results provide us with empirical support for our baseline expectation that even if Russian citizens see nuclear weapons as an important aspect of their country's identity, they are generally averse to the idea of their direct military use.

To our surprise, the number of participants who disagreed with nuclear use held steady even when the nuclear explosion was "merely" demonstrative in an unpopulated area. In fact, a simple comparison of the results in treatments B and C show that there was significantly higher support for a conventional strike resulting in a high number of deaths among NATO soldiers and Polish civilians than for a nuclear explosion absent of collateral damage. At the same time, we saw that most respondents indicated that they had been concerned about civilian casualties (see below), and that they clearly differentiated between the two types of nuclear strike: were they to choose, a majority would prefer a demonstrative explosion. What to make of these findings?

Our interpretation is that most Russians are categorically against the first use of nuclear weapons in a conflict with NATO, and their views, therefore, do not seem to be particularly elastic with respect to the expected number of fatalities or, as we saw in the comparison of treatments A and D, to a discernible escalation of the conflict. At present, we have no data to 
see to what extent this aversion to first use is absolute. Perhaps, we would see a shift in attitudes if the conflict escalated further and the very existence of Russia was in jeopardy, if the enemy used other weapons of mass destruction in the conflict, or targeted large civilian population centers rather than military targets. From a policy perspective, however, our findings provide an important indication that the Kremlin probably cannot count on public support for a nuclear “escalate-to-deescalate" strike under the scenarios of a conflict on NATO's eastern flank that are commonly described in the Western expert literature.

How do Russian attitudes compare with those of the public in Western countries? As noted in the introduction, we need to be cautious about these comparisons as we did not engage in a direct replication of earlier studies. That being said, at first glance, Russians do appear to be somewhat more averse to the military use of nuclear weapons than Americans. For example, Sagan and Valentino (2017) found that about 59\% of Americans would approve of a nuclear strike that results in 2,000,000 Iranian civilian deaths if it saved 20,000 U.S. troops. Still, more fitting is the comparison with a study by Haworth, Sagan, and Valentino (2019), where half of U.S. respondents approved of using nuclear weapons against North Korea in response to its ballistic missile test, even though the strike would result in a large number of civilian fatalities and there was also a chance that Pyongyang would retaliate with nuclear weapons. Koch and Wells (2020) found close to $40 \%$ support for a nuclear strike against an unnamed nuclear-armed state's city that hosts the country's nuclear arsenal, and public insensitivity to the varying levels of retaliation risk. The level of approval in our study appears to be most comparable with a recent study in Germany, where $12 \%$ of the public agreed with a nuclear "de-escalatory" strike in a conflict between NATO and Russia in the Baltics, 61\% disagreed, and 27\% did not know (Onderco and Smetana 2021). Future research should employ cross-national survey designs that would allow for a direct comparison of attitudes in different countries - for example, one could design a nuclear-use scenario similar to that of Press, Sagan, and Valentino (2013), to discover 
how supportive Russians would be of the employment of nuclear weapons against terrorist groups developing weapons of mass destruction that could be used against their compatriots.

Our study also contributes an important finding concerning the application of the MFT, a promising theoretical framework to study moral intuitions of individuals in our field (cf. Price and Sikkink 2021). Graham et al. (2011) previously found that while the MFT has universal applicability, there are substantial cross-cultural variations across regions, particularly with respect to the differences between Western and non-Western countries. We found that in Russia, individualizing moral foundations are strongly associated with aversion to the strikes, in a similar way as in the United States (Rathbun \& Stein 2020; Smetana \& Vranka 2021). The association between strike support and binding foundations appears to have a somewhat weaker yet still statistically significant effect.

However, as Smetana and Vranka (2021) found, there were no significant interactions between moral foundations and the type of strike in our experiment. This suggests that while moral foundations serve as a good predictor of nuclear (non-)use attitudes, they are not linked to nuclear weapons per se, but they are primarily associated with an overall "hawkishness" in foreign policy, along the lines of research by Kertzer et al. (2014). These findings also possibly suggest that neither Americans nor Russians have developed specific moral barriers with respect to nuclear weapons and the five moral foundations, but they see nuclear use (perhaps in any form, as shown in the demonstrative condition) as a dramatic extension of the conventional use of military force and they are mindful of the exceptional impact of a nuclear strike without intuitively linking this impact to some specific moral concerns.

At the forefront of respondents' self-reported concerns about the use of force were civilian casualties, the suffering of victims, and the impact on the environment. Incidentally, these "liberal" concerns are today at the forefront of the global "humanitarian initiative" to ban nuclear weapons (Borrie 2014; Rosendorf, Smetana, and Vranka 2021), which recently 
culminated in the adoption of the Treaty on the Prohibition of Nuclear Weapons (Considine 2019; Müller and Wunderlich 2020). The moral imperative to minimize civilian casualties in war corresponds to the research of Dill and Schubiger (2020), who found it to influence greatly public views on the use of force. Our findings stand in contrast to Press, Sagan, and Valentino (2013) and Sagan and Valentino (2017), who identified the strategic considerations - setting a dangerous precedent - at the forefront of their respondents' concerns (only the fourth most important concern in our study). Interestingly, the concerns that follow from deterrence literature - that is, the risk of nuclear or conventional retaliation - clearly played a much smaller role in the self-reported reasoning of our survey participants.

It is important to note that we found no statistically significant differences in the reasoning and the relative importance of concerns between participants in nuclear and conventional conditions. This finding suggests that the basic structure of concerns holds irrespective of the weapon type, and the concerns, therefore, appear to be primarily tied to the use of military force as such - in line with our finding about the relationship between moral foundations and strike support discussed above. Overall, it seems that neither the moral intuitions nor self-reported reasoning of the Russian public differ significantly for nuclear and conventional weapons. However, as seen in our experimental scenarios, most individuals still clearly differentiate between nuclear and conventional strikes and have internalized the image of nuclear weapons as a form of military force so drastic that it trumps the use of conventional missiles even in cases when they are told that the strike is merely demonstrative, absent of direct casualties. Further studies, perhaps including focus groups in addition to large-N surveys, are certainly needed to unravel the complex internal process behind the respondents' attitudes.

A comparative analysis of the concerns of those who approved and those who disapproved of the strikes nevertheless provides some interesting speculations about the factors behind participants' approval and disapproval. Most importantly, those who disagreed with the 
strikes had been much more concerned about the suffering of victims, environmental impact, the logic of precedent, morality, and international law. Those who agreed with the strikes, on the other hand, seemed to put relatively more weight on the concerns about retaliation, Russia's reputation, and weapon effectiveness. Moreover, for these participants, a desire to punish NATO for its actions was relatively much more important - in line with the work of Sagan and Valentino (2017) and Rathbun and Stein (2020), who found that that retribution was a powerful driver behind the willingness to support nuclear use.

Although we did not explicitly formulate any hypotheses regarding the sociodemographic factors, we wish to highlight a strong and qualitatively intriguing association between gender and the attitude to the use of force in our study. Russian women are clearly more averse to any kind of proposed military strikes in the conflict, in line with earlier research on a "gender gap" in views on the use of military force in the West (Eichenberg 2016; Clements and Thomson 2021). Russian men seem to differentiate more between the two types of strikes: while they seem to be relatively supportive of conventional strikes, their disapproving views become much closer to those of Russian women in the nuclear domain - an interesting finding that, in our view, warrants further research in the future.

Once again, it is important to note that all our scenarios portrayed the first use of nuclear weapons in a conflict with NATO. This is in line with the "nuclear taboo" literature that frequently stresses that the "taboo" applies to the military first use of nuclear weapons and does not necessarily present the same normative constrains as retaliatory second strikes (Tannenwald 2007, p. 57). Similarly, the concept of the nuclear nonuse "tradition" explicitly built on the idea of a strategic pattern where it is in the interest of all relevant actors not to disrupt it by being the first to employ nuclear weapons in a military conflict - once the tradition is broken, all bets are off (Paul 2009). Future research of Russian attitudes should investigate the change in 
approval of nuclear use in a situation when it is the other side that introduces nuclear weapons to the conflict first.

A reader may be wondering to what extent public opinion on these issues is even relevant in Russia. Despite being a non-democratic country, prior research has demonstrated that the views of the Russian public do matter for elite decision-making. In fact, the manufacturing of domestic consent in foreign and defense policy has become increasingly important for the ruling elite in Moscow over the years. As Gudkov (2019) argues, there is a link between militarism, foreign policy adventurism, and the suppression of domestic dissent in contemporary Russia (see also Snegovaya 2020; Sirotkina and Zavadskaya 2020). The shaping of public opinion on nuclear weapons, along with other defense issues, has become the key tool in President Putin's toolbox (Wagner 2021; Kolesnikov 2016) - which is why, for example, nuclear missiles are regularly paraded on Victory Day in Moscow, and shops sell tshirts with quips like "Sanctions? Don't make my Iskandar laugh" (Deriglazova and Rozhanovskaya 2020, 154). The importance of public opinion in contemporary Russia also corresponds to more general claims about the relevance of public views for non-democratic regimes. As Frye $(2019,971)$ argues, “[b]ecause mass revolts are a key threat to autocratic regimes, and because policy success depends in part on popular support, autocratic rulers have strong incentives to shape public opinion" and "monitor public opinion closely and devote considerable resources to sway popular sentiment" (for an elaboration of this argument, see Wilson, 2005).

\section{Conclusions and avenues for further research}

At the time of finishing this paper, the specter of war continues to loom large over the European continent, with Moscow amassing its troops near the border with Ukraine and presenting its demands to the representatives of NATO countries. The sheer size of the Russian nuclear arsenal and its political and strategic importance for the Kremlin have made the possible use of 
nuclear weapons in the region a pertinent concern among Western experts and policymakers alike. To the best of our knowledge, our paper is the first to employ experimental survey methodology to examine Russian public attitudes toward nuclear weapon use. To some extent, our findings may be reassuring: even though Russians are generally supportive of their country's nuclear arsenal and see it as a symbol of Russia's great-power status, we found that they are simultaneously strongly averse to their military use.

From a broader scholarly perspective, our paper is a unique contribution to the literature on attitudes toward nuclear (non-)use by examining the views of the public in a non-Western and non-democratic country. To this end, we would like to propose three promising avenues for follow-up research. First, Russia is a rather specific country with respect to nuclear weapons: it has possessed a nuclear arsenal since the late 1940s and, together with the United States, crafted the key pillars of the global nuclear order. Over the decades, the adoption of arms control institutions and practices brought Russia closer to Western nuclear states in many pertinent aspects (Holloway 2016; Potter and Bidgood 2018). While Russia is certainly a relevant nonWestern country for the study of nuclear nonuse norms, future research should go further and explore to what extent the attitudes toward nuclear use are similar in non-Western countries with shorter nuclear histories and lower levels of the institutionalization of the norms of nuclear order - such as India or Pakistan.

Second, future research should address the sources of cross-national variation in nuclear nonuse attitudes. It is reasonable to expect that divergent historical experiences, culture, and generally views on the use of force in world politics may help to explain the differences among countries. We, however, need to employ survey experiments using directly comparable scenarios to test these claims with empirical evidence and identify the key causal factors.

Third, researchers interested in exploring the "nuclear taboo" in the Russian Federation should follow closely the latest attempts to survey Russian elites on matters of foreign policy 
(Rivera and Zimmerman 2019). Whether there are significant differences in public and elite attitudes and how can we explain them are today among the central questions of interest in survey research in our field (Hafner-Burton, Hughes, and Victor 2013; Kertzer 2020). The gaps in Russian elite and public attitudes toward nuclear nonuse remain uncharted territory and an exciting area for future research.

\section{References}

Akhtamzyan, Ildar. 2006. Attitudes in the Russsian Federation towards WMD Proliferation and Terrorism. PIR Center Report. Moscow: Human Rights Publishers.

Borrie, John. 2014. "Humanitarian Reframing of Nuclear Weapons and the Logic of a Ban." International Affairs 90 (3): 625-46.

Bowen, Tyler, Michael Goldfien, and Matthew Graham. 2021. "The Illusory Nuclear Taboo." Yale Working Paper.

Carpenter, Charli, Alexander H. Montgomery, and Alexandria Nylen. 2020. "Breaking Bad? How Survey Experiments Prime Americans for War Crimes.” Perspectives on Politics, $1-13$.

Cimbala, Stephen J., and Roger N. McDermott. 2016. "Putin and the Nuclear Dimension to Russian Strategy.” Journal of Slavic Military Studies 29 (4): 535-53.

Clements, Ben, and Catarina P Thomson. 2021. "The 'Ultimate Insurance' or an 'Irrelevance' for National Security Needs? Partisanship, Foreign Policy Attitudes, and the Gender Gap in British Public Opinion towards Nuclear Weapons.” European Journal of International Security, 1-22.

Considine, Laura. 2019. "Contests of Legitimacy and Value: The Treaty on the Prohibition of Nuclear Weapons and the Logic of Prohibition." International Affairs 95 (5): 1075-92.

Cooper, David A. 2021. Arms Control for the Third Nuclear Age : Between Disarmament and Armageddon. Washington, D.C.: Georgetown University Press. 
Davis, Paul, J. Gilmore, David Frelinger, Edward Geist, Christopher Gilmore, Jenny Oberholtzer, and Danielle Tarraf. 2019. Exploring the Role Nuclear Weapons Could Play in Deterring Russian Threats to the Baltic States. Santa Monica, CA: RAND Corporation.

Deriglazova, Larisa, and Nina Rozhanovskaya. 2020. "Building Nuclear Consensus in Contemporary Russia: Factors and Perceptions.” In Nuclear Russia: International and Domestic Agendas, edited by Andrey Pavlov and Larisa Deriglazova, 131-62. Tomsk: Tomsk University Press.

Dill, J, and LI Schubiger. 2020. “Attitudes towards the Use of Force: Instrumental Imperatives, Moral Principles and International Law.” American Journal of Political Science.

Dill, Janina, Scott D. Sagan, and Benjamin A. Valentino. 2021. "Public Opinion on the Nuclear Taboo and Non-Combatant Immunity Norms in the United States, the United Kingdom, France, and Israel." Working Paper.

Dogruyol, Burak, Sinan Alper, and Onurcan Yilmaz. 2019. “The Five-Factor Model of the Moral Foundations Theory Is Stable across WEIRD and Non-WEIRD Cultures.” Personality and Individual Differences 151.

Egel, Naomi, and R Lincoln Hines. 2021. “Chinese Views on Nuclear Weapons: Evidence from an Online Survey." Research and Politics.

Eichenberg, Richard C. 2016. "Gender Difference in American Public Opinion on the Use of Military Force, 1982-2013.” International Studies Quarterly 60 (1): 138-48.

Fink, Anya Loukianova. 2017. “The Evolving Russian Concept of Strategic Deterrence: Risks and Responses." Arms Control Today 47 (6): 14-20.

Fink, Anya Loukianova, and Olga Oliker. 2020. “Russia’s Nuclear Weapons in a Multipolar World: Guarantors of Sovereignty, Great Power Status \& More.” Daedalus 149 (2): 37- 
55.

Frye, Timothy. 2019. "Economic Sanctions and Public Opinion: Survey Experiments From Russia." Comparative Political Studies 52 (7): 967-94.

Futter, Andrew, and Benjamin Zala. 2021. "Strategic Non-Nuclear Weapons and the Onset of a Third Nuclear Age.” European Journal of International Security 6 (3): 257-77.

Graham, Jesse, Jonathan Haidt, Sena Koleva, Matt Motyl, Ravi Iyer, Sean P. Wojcik, and Peter H. Ditto. 2013. "Moral Foundations Theory: The Pragmatic Validity of Moral Pluralism." Advances in Experimental Social Psychology 47: 55-130.

Graham, Jesse, Jonathan Haidt, and Brian A. Nosek. 2009. "Liberals and Conservatives Rely on Different Sets of Moral Foundations." Journal of Personality and Social Psychology 96 (5): 1029-46.

Graham, Jesse, Brian A. Nosek, Jonathan Haidt, Ravi Iyer, Spassena Koleva, and Peter H. Ditto. 2011. "Mapping the Moral Domain.” Journal of Personality and Social Psychology 101 (2): 366-85.

Gudkov, Lev. 2019. Russian Public Opinion and the Confrontation with the West. Oslo: Norwegian Institute of International Affairs.

Hafner-Burton, Emilie M., D. Alex Hughes, and David G. Victor. 2013. “The Cognitive Revolution and the Political Psychology of Elite Decision Making." Perspectives on Politics 11 (02): 368-86.

Haidt, Jonathan, and Craig Joseph. 2004. "Intuitive Ethics: How Innately Prepared Intuitions Generate Culturally Variable Virtues.” Daedalus 133 (4): 55-66.

Haworth, Alida R., Scott D. Sagan, and Benjamin A. Valentino. 2019. "What Do Americans Really Think about Conflict with Nuclear North Korea? The Answer Is Both Reassuring and Disturbing." Bulletin of the Atomic Scientists 75 (4): 179-186.

Holloway, David. 2016. “The Soviet Union and the Creation of the International Atomic 
Energy Agency." Cold War History 16 (2): 177-93.

Horschig, Doreen. 2021. "Israeli Public Opinion on the Use of Nuclear Weapons: Lessons From Terror Management Theory." Paper Presented at the 2021 ISA Annual Convention.

Jervis, Robert. 1984. The Illogic of American Nuclear Strategy. Ithaca: Cornell University Press.

Johnson, Dave. 2018. “Russia’s Conventional Precision Strike Capabilities, Regional Crises, and Nuclear Thresholds." Livermore Papers on Global Security, no. 3. https://cgsr.llnl.gov/content/assets/docs/Precision-Strike-Capabilities-report-v3-7.pdf.

Kertzer, Joshua D., Kathleen E. Powers, Brian C. Rathbun, and Ravi Iyer. 2014. "Moral Support: How Moral Values Shape Foreign Policy Attitudes.” Journal of Politics 76 (3): $825-40$.

Kertzer, Joshua D. 2020. "Re-Assessing Elite-Public Gaps in Political Behavior.” American Journal of Political Science, 1-48.

Koch, Lisa Langdon, and Matthew Wells. 2020. 'Still Taboo? Citizens' Attitudes toward the Use of Nuclear Weapons.” Journal of Global Security Studies 6 (3): 1-18.

Kolesnikov, Andrei. 2016. Do Russians Want War? Moscow: Carnegie Moscow Center. Kristensen, Hans M., and Matt Korda. 2021. "Russian Nuclear Weapons, 2021.” Bulletin of the Atomic Scientists 77 (2): 90-108.

Kroenig, Matthew. 2018. “A Strategy for Deterring Russian Nuclear De-Escalation Strikes.” Washington, D.C. http://www.atlanticcouncil.org/images/Nuclear_Strategy_WEB.pdf. Kühn, Ulrich. 2018. Preventing Escalation in the Baltics: A NATO Playbook. Washington, DC: Carnegie Endowment for International Peace. https://carnegieendowment.org/files/Kuhn_Baltics_INT_final_WEB.pdf. Levada Center. 2019. “Russian Public Opinion 2018.” https://www.levada.ru/cp/wp- 
content/uploads/2019/07/2018-Eng.pdf.

Ludvik, Jan. 2019. "Closing the Window of Vulnerability: Nuclear Proliferation and Conventional Retaliation.” Security Studies 28 (1): 87-115.

Luik, Jüri, and Tomas Jermalavicius. 2017. "A Plausible Scenario of Nuclear War in Europe, and How to Deter It: A Perspective from Estonia.” Bulletin of the Atomic Scientists 73 (4): 233-39.

Montgomery, Alexander, and Charli Carpenter. 2020. "The Stopping Power of Norms: Saturation Bombing, Civilian Immunity, and U.S. Attitudes toward the Laws of War." International Security 45 (2): 140-169.

Mueller, John E. 2012. Atomic Obsession: Nuclear Alarmism from Hiroshima to Al-Qaeda. Oxford: Oxford University Press.

Müller, Harald, and Carmen Wunderlich. 2020. "Nuclear Disarmament without the NuclearWeapon States: The Nuclear Weapon Ban Treaty.” Daedalus 149 (2): 171-89.

Oliker, Olga, and Andrey Baklitskiy. 2018. "The Nuclear Posture Review and Russian 'DeEscalation': A Dangerous Solution to a Nonexistent Problem,” February 20, 2018. https://warontherocks.com/2018/02/nuclear-posture-review-russian-de-escalationdangerous-solution-nonexistent-problem/.

Onderco, Michal, and Michal Smetana. 2021. "German Views on US Nuclear Weapons in Europe: Public and Elite Perspectives.” European Security 30 (4): 30:4, 630-648.

Paul, T.V. 2009. The Tradition of Non-Use of Nuclear Weapons. Stanford: Stanford University Press.

Potter, William C., and Sarah Bidgood, eds. 2018. Once and Future Partners: The United States, Russia and Nuclear Non-Proliferation. London: Routledge.

Press, Daryl G., Scott D. Sagan, and Benjamin A. Valentino. 2013. “Atomic Aversion: Experimental Evidence on Taboos, Traditions, and the Non-Use of Nuclear Weapons.” 
American Political Science Review 107 (1): 188-206.

Price, Richard, and Kathryn Sikkink. 2021. International Norms, Moral Psychology, and Neuroscience. Cambridge: Cambridge University Press.

Putin, Vladimir. 2020. "Basic Principles of State Policy of the Russian Federation on Nuclear Deterrence,” June 8, 2020.

https://www.mid.ru/en/foreign_policy/international_safety/regprla//asset_publisher/YCxLFJnKuD1W/content/id/4152094.

Rathbun, Brian C., and Rachel Stein. 2020. “Greater Goods: Morality and Attitudes toward the Use of Nuclear Weapons.” Journal of Conflict Resolution 64 (5): 787-816.

Rivera, Sharon Werning, and William Zimmerman. 2019. "Introduction: New Directions in Survey Research on Russian Elites.” Post-Soviet Affairs 35 (5-6): 359-64.

Rosendorf, Ondrej, Michal Smetana, and Marek Vranka. 2021. "Disarming Arguments: Public Opinion and Nuclear Abolition.” Survival 63 (6): 183-200.

Sagan, Scott. 2004. "Realist Perspectives on Ethical Norms and Weapons of Mass Destruction." In Ethics and Weapons of Mass Destruction: Religious and Secular Perspectives, edited by Sohail H. Hashmi and Steven P. Lee, 73-95. Cambridge: Cambridge University Press.

Sagan, Scott D., and Benjamin A. Valentino. 2017. "Revisiting Hiroshima in Iran: What Americans Really Think about Using Nuclear Weapons and Killing Noncombatants.” International Security 42 (1): 41-79.

Sauer, Frank. 2015. Atomic Anxiety: Deterrence, Taboo and the Non-Use of U.S. Nuclear Weapons. London: Palgrave Macmillan.

Schneider, Mark B. 2018. "Russian Nuclear 'de-Escalation' of Future War.” Comparative Strategy 37 (5): 361-72.

Sherrill, Clifton W. 2018. “The Myth of the Nuclear Taboo.” Asian International Studies 
Review 18 (1): 1-21.

Sirotkina, Elena, and Margarita Zavadskaya. 2020. "When the Party's over: Political Blame Attribution under an Electoral Authoritarian Regime.” Post-Soviet Affairs 36 (1): 37-60.

Smetana, Michal. 2018. “A Nuclear Posture Review for the Third Nuclear Age.” The Washington Quarterly 41 (3): 137-57.

Smetana, Michal, and Marek Vranka. 2021. "How Moral Foundations Shape Public Approval of Nuclear, Chemical, and Conventional Strikes: New Evidence from Experimental Surveys.” International Interactions 47 (2): 374-390.

Smetana, Michal, and Carmen Wunderlich. 2021. "Forum: Nonuse of Nuclear Weapons in World Politics: Toward the Third Generation of 'Nuclear Taboo' Research.” International Studies Review 23 (3) 1072-1099.

Snegovaya, Maria. 2020. “Guns to Butter: Sociotropic Concerns and Foreign Policy Preferences in Russia.” Post-Soviet Affairs 36 (3): 268-79.

Sokov, Nikolai N. 2014. "Why Russia Calls a Limited Nuclear Strike 'de-Escalation."” Bulletin of the Atomic Scientists, March 13, 2014. https://thebulletin.org/why-russiacalls-limited-nuclear-strike-de-escalation.

Steinbruner, John, and Nancy Gallagher. 2008. "If You Lead, They Will Follow: Public Opinion and Repairing the U.S.-Russian Strategic Relationship.” Arms Control Today. https://www.armscontrol.org/act/2008-01/features/if-you-lead-they-follow-publicopinion-repairing-us-russian-strategic.

Sukin, Lauren. 2020. "Experimental Evidence on Determinants of Support for Nuclear Use in Response to Threats of Nuclear Retaliation.” Peace and Conflict 26 (3): 336-39. Tannenwald, Nina. 2007. The Nuclear Taboo: The United States and the Non-Use of Nuclear Weapons Since 1945. Cambridge: Cambridge University Press.

Ven Bruusgaard, Kristin. 2017. “The Myth of Russia’s Lowered Nuclear Treshold,” 
September 22, 2017. https://warontherocks.com/2017/09/the-myth-of-russias-lowerednuclear-threshold/.

—. 2020. "Russian Nuclear Strategy and Conventional Inferiority." Journal of Strategic Studies 00 (00): 1-33.

Wagner, Anna. 2021. "Public Opinion on Nuclear Weapons and Arms Control in Russia." In On the Horizon: A Collection of Papers from the Next Generation, edited by Reja Younis, 161-73. Washington, D.C.: Center for Nonproliferation Studies.

Walker, William. 2010. "The Absence of a Taboo on the Possession of Nuclear Weapons." Review of International Studies 36 (4): 865-76.

Waltz, Kenneth N. 1981. “The Spread of Nuclear Weapons: More May Be Better: Introduction.” The Adelphi Papers 21 (171).

Wilson, Andrew. 2005. Virtual Politics: Faking Democracy in the Postcommunist World. New Haven, CT: Yale University Press.

Zimmerman, William. 2002. The Russian People and Foreign Policy: Russian Elite and Mass Perspectives, 1993-2000. Princeton: Princeton University Press.

Zysk, Katarzyna. 2018. "Escalation and Nuclear Weapons in Russia’s Military Strategy." RUSI Journal 163 (2): 4-15. 